\title{
SENSES AND BEHAVIOR OF INTERACTIVE ENVIRONMENT Boychenko K.
}

\author{
Boychenko Kristina Viktorovna-Master of science in Architecture, \\ department of architecture, ingeneering \\ Polytechnic university of milan, Milan, Italy
}

\begin{abstract}
: interactive architecture is a new trend in design, based on communication of user and the space, the ability of the space to respond in real time and to accommodate different and changing needs of the users in a more effective way, creating continuous relationship between the society and the built environment. Interactive built environment is now able to receive and process information and perform actions according to the situation, therefore acting as a member of society, communicating with users.
\end{abstract}

Keywords: interactive architecture, smart environment, behavior, senses, communication, society.

\section{ЧУВСТВА И ПОВЕДЕНИЕ ИНТЕРАКТИВНОЙ СРЕДЫ Бойченко К. В.}

\author{
Бойченко Кристина Викторовна - магистрант, \\ кафедра архитектуры, факультет архитектуры и инженерии, \\ Миланский политехнический университет, г. Милан, Италия
}

\begin{abstract}
Аннотация: интерактивная архитектура является новой тенденцией в проектировании, основанной на коммуникации потребителя и пространства, способности пространства отвечать в режиме реального времени и соответствовать разным и изменяющимся потребностям пользователей более эффективным способом, создавая непрерывную связь между обществом и антропогенной средой. Сейчас интерактивная окружающяая среда способна принимать и обрабатьвать информацию, а также предпринимать действия в соответствии с ситуацией, становясь членом общества и взаимодействуя с пользователями.
\end{abstract}

Ключевые слова: интерактивная архитектура, умная среда, поведение, чувства, взаимодействие, общество.

Bertsky argues that our culture is supersaturated with effects, in other words, the entire production process is hidden from us. We are surrounded by effects. All magically appears from nowhere, only the result is exposed. Therefore, in this conditions the architecture should operate on the level of effects as well [1].

Ben van Berkel says that the role of architecture is to make us understand ourselves and the world around us in a new way, remain a mirror for the real world" [2].

On the edge of interactivity and dynamism there emerged an idea of slow-acting space, first designed by Michael Bell. It can be described as non-stop, slow and anti-static space. The purpose of this space is to slow down the perception of surrounding space enough to give an opportunity to understand where you are. The effects used to achieve this perception are not necessarily functional, but they affect the functionality. They may not have come from the place' specific features, but they describe the place. They are not constructive, but they are related to the structure.

With the development of new technical capabilities, "smart objects" start being able to receive a lot of information from the external environment. The people's behavior is a significant part of this environment. This leads to necessity of understanding the feedback with the world and the notion of "family of smart objects" in our environment that can communicate with us and with each other by sending messages using the built-in microprocessors which are giving different information. A lot of these components are designed to capture information from the environment, such as temperature, light levels, wind speed and noise. Some components are able to receive simple messages from users. They feel our presence radiated heat or movement and react in some way [3].

Interactive architecture is based on the actions. Actions take place in the environment all the time, they create it and define it as such. Performance evaluation system is required for design and post-design analysis. A number of methods of approach to the analysis of activities has developed in engineering and psychological research. One of them is focused on the selection of activities and operations in the "activity stream", on recognition of relationship and mutual transitions between them. Within this method the so-called algorithmic methods, methods of structural and statistical analysis are often used for description of actions. These methods make it possible to approach the assessment of psychological tension and the degree of diversity (or monotony) of workflow and operations. The second approach is described from the point of view of the requirements that are imposed to perception during the activity, attention, memory, thinking, etc. 
As an example of a project object with sensibility as its' main function may serve the D-Tower project by NOX. The d-tower is large installation, creating an animation in the urban space. Visually it is perceived as a design object, not endowed with the practical problems at first glance, but the tower is not simply exposed, it serves the society. It's a whole interactive project in which the architecture is a part of interactive relationship, involved in the psychological monitoring of residents, their inner feelings and manifestations. In addition to the tower, project includes a survey and a website. All three parts are connected interactively with each other. Every month residents' answers to the questionnaire are shown on the site in the form of graphs. A selection of responses is constantly updated on the site, this experimental study involves all 50,000 residents of Doetinchem. The survey questions relate to the emotions that we experience every day, such as hate, love, happiness and fear. The answers are defined by four colors: green, red, blue and yellow, illuminating the tower. The illumination is directly connected to the website, every evening the tower lights up with the color of the emotion that prevailed on that day [4].

Oosterhuis defines the space that behaves and acts driven by its' programs and performs many actors, among them people, light bulbs, refrigerators, vacuum cleaners, sofas, shopping, bookshelves, tables and chairs. They all move or move in a certain space. In the context of Swarm architecture all the actors / players behave with accordance to each other by following some simple rules, forming the space which defines the working space of the players. Going further, this space interacts with other spaces. From here on the designer gives the way to swarm of players interacting within the space of their semi-permeable membranes, and begins to control a swarm of interacting spaces. The people flow from space to space, from the car into the space of the small space to the vast space. From the spatial point of view, people operate the space as if they control the computer. Just like the computer calculates, the space performs the calculation and converts the information content into material absorbed by this space. People also do calculate, but in their own sphere: they consume food and drink, they absorb sound and light, they smell and feel. People are the transformers the, and the spaces are the transformers at the meta-level comparing to the people [5].

Oosterhuis uses the Swarm Architecture as a more elaborated background for the Interactive architecture, performing further research about intelligent e-motive environment and structures based on parametric methods.

The ultimate goal of Swarm architecture is to keep its' new structures up-to dated in real time. The objective of information architecture projects is to support the vitality of the process and apply the values to the behavior in real-time, to understand how can the designers create a tunnel for a continuous flow of data within the built structure, where the content is constantly changing in real time? To facilitate this fundamentally new view of the world, we have to look at the building as if they are appliances that can be run in real-time. These dynamic buildings by Oosterhuis can be considered as existing processes that continuously inform users and are informed themselves continuously during other active processes. They are the active nodes in a complex adaptive operating network [6].

Thus, people operate processes directly as well. Using the new techniques, they cooperate to create efficient buildings, which also considered as highly applicable processes. The buildings become active installations, where multiple control devices are constantly communicating with other control devices, their users and their environment. We know from practice that there is a large proportion of the budget devoted to electrical and mechanical installations for every building, taking up to $30 \%$ of the total budget. In the bright future of buildings, the entire structure will be interpreted as the installation. Projecting current trends into the near future, it makes sense to consider all the components of built structure as active members of the installation. The building becomes the instrument, it becomes an installing itself.

From this point it is fare to consider interactive installations. Most of the art or design installations have a temporary nature. They exist only for the period of the exhibition. Assuming that an art installation would last throughout the whole life cycle of the building, there emerges a quite precise image of the installation building. We live in an installation space of performance. ONL developed the concept of buildings as large-scale sculptures in the urban Sculpture City project (Rotterdam, 1994). Buildings could be clearly sculptures and sculpture can function as a building without compromising the value of the sculpture. Oosterhuis proposes to take the next step: to consider building / sculpture as an active installation, and to consider the city as a swarm of interactive installations. A sculpture building is an object that is generated according to a series of intuitive acts and logical instructions, both in the phase of the virtual design and in the phase of the materialization . The functionality of the building is just one out of thousands of parameters effecting the resulting image of the concept. With each step in the series of instructions and acts the functionality of the building is equivalent to other parameters. There is no hierarchy of arguments but their procedure. Forget the city as a collection of static objects, it is just a minor detail quantized urban game. In the near future, ONL is planning to come up with a project called the installation City.

\section{Список литературы / References}

1. Belogolovskiy Vladimir. Interview with Aaron Betsky // Architectural herald, 2006. № 2 (89). 
1. Van Berkel Ben and Bos Caroline, Move // Paperback, 1999.

2. Kereshun Alyena Abilities of Interactive Architecture // Architecton: university news, 2006. № 14. Jul .

3. Lars Spuybroek, NOX Architects // D-Tower. [Electronic resource]. URL: http://www.nox-artarchitecture.com/ (date of access: 03.02.2017).

4. Oosterhuis Kas. Swarm Architecture II // TU Delft, 2006.

5. Oosterhuis Kas. Towards a New Kind of Building: A Designers Guide for Nonstandard Architecture // TU Delft, 2004.

6. Alexenberg Mel. The Future of Art in a Postdigital Age: From Hellenistic to Hebraic Consciousness // Bristol and Chicago: Intellect Books/University of Chicago Press, 2011. 